\title{
Pengaruh Self-efficacy dan Prokastinasi Akademik Terhadap Motivasi Berprestasi Pada Mahasiswa PAUD IKIP Veteran Semarang
}

\author{
Widya Novi A Dewi ; Inayatul Khafidhoh \\ 1) Dosen Bimbingan dan Konseling FKIP IVET Semarang \\ 2) Dosen Bimbingan dan Konseling IAIN Kudus
}

Program Studi Bimbingan dan Konseling

Universitas IVET Semarang dan IAIN Kudus

\begin{abstract}
Abstrak
Penelitian ini bertujuan untuk mengetahui pengaruh self-efficacy dan prokastinasi akademik terhadap motivasi berprestasi pada mahasiswa PAUD IKIP Veteran Semarang. Penelitian menggunakan metode kuantitatif dengan analisis regresi. Data diambil kepada 79 mahasiswa PAUD IKIP Veteran Semarang secara random sampling. Berdasarkan hasil regresi pada variabel self-efficacy diperoleh thitung $=2,236$ dengan probabilitas $0,028<0,05$ dan Rsquare 0,381 artinya ada pengaruh signifikan antara self-efficacy dengan motivasi berprestasi. Sedangkan pada prokastinasi akademik nilai t hitung=-5,009 dengan probabilitas $0,000<0,05$ yang berarti ada pengaruh yang signifikan antara prokrastinasi akademik dengan motivasi berprestasi.

Kata kunci: self-efficacy, prokrastinasi akademik, motivasi berprestasi
\end{abstract}

\begin{abstract}
The research aimed at knowing the effect of self-efficacy and academic procastination on achievement motivation in students of IKIP Veteran Semarang. The research used quantitative method with regression analysis. Data was obtaine through 79 respondent with random sampling. Based on regression result on self efficacy variable obtained tcount $=$ 2,236 with probability $0,028<0,05$ and Rsquare 0,381 meaning there is influence between self-efficacy with achievement motivation. While on academic procastination $\mathrm{t}$ arithmetic $=-5.009$ with probability $0.000<0.05$ which means there is a significant influence between academic procrastination with achievement motivation.
\end{abstract}

Keywords: self-efficacy, academic procrastination, achievement motivation 


\section{PENDAHULUAN}

Belajar di perguruan tinggi sangatlah berbeda dengan belajar di tingkat sebelumnya yaitu belajar di SMA, SMK atau sederajatnya. Belajar di perguruan tinggi memerlukan kemandirian dan disiplin pribadi. Mahasiswa sebagau individu yang berkembang dan belajar di perguruan tinggi perlu memiliki kapasitas potensi yang berua inisiatif, karena inisiatif merupakan landasan dasar perilaku mahasiswa dalam melakukan perilaku mencari pertolongan terkait penguasaan materi perkuliahan (Furchan, 2009).

Kedudukan mahasiswa sebagai seorang akademisi di perguruan tinggi akan selalu berhadapan dengan tugas yang bersifat akademik maupun non akademik. Adapun yang bersifat akademik seorang mahasiswa tidak terlepas dari tugas yang diberikan oleh masing-masing dosen pada setiap mata kuliah, bahkan dalam satu semester volume tugas tersebut mencapai sepuluh hingga lima belas makalah yang harus diselesaikan dengan baik dan tepat waktu. Dengan tingginya beban tugas perkuliahan di perguruan tinggi, maka seorang mahasiswa dituntut memiliki self-efficacy yang tinggi sehingga terhindar dari sikap menunda-nunda atau prokrastinasi akademik.

Bandura menjelaskan bahwa self efficacy merupakan keyakinan mempengaruhi pilihan orang dalam membuat dan menjalankan tindakan yang mereka kejar. Keyakinan efficacy juga membantu menentukan sejauh mana usaha yang akan dikerahkan orang dalam suatu aktivitas, seberapa lama mereka akan gigih ketika menghadapi rintangan, dan seberapa ulet mereka akan menghadapi situasi yang tidak cocok. Keyakinan efficacy juga mempengaruhi tingkat stress dan kecemasan individu sehingga mereka menyibukkan diri dalam suatu aktifitas (Feist,2008).

Bandura (1997) menyebutkan tiga aspek yang terdapat pada self efficacy yaitu: (a) Tingkat kesulitan tugas (level). Berkaitan dengan tingkat kesulitan suatu tugas yang dilakukan. (b) Luas bidang tugas (Generality), berkaitan dengan seberapa luas individu mempunyai keyakinan dalam melaksanakan tugastugas. Ada individu yang merasa yakin pada bidang tugas tertentu, ada individu yang merasa yakin pada banyak bidang tugas. (c) Tingkat kekuatan (Strength), individu yang mempunyai self efficacy yang lemah akan mudah menyerah, sebaliknya individu yang memiliki keyakinan yang kuat terhadap kemampuannya akan gigih dalam berusaha meskipun banyak hambatan, kesulitan, serta pengalaman yang tidak menunjang.

Sebuah studi nasional yang dilakukan oleh Asosiasi Kesehatan Universitas Amerika (2008) terhadap lebih dari 90.000 mahasiswa di 177 kampus mengungkapkan bahwa merasa tidak punya harapan, merasa kewalahan dengan hal-hal yang mereka lakukan, mengalami kelelahan mental, sedih dan merasa depresi adalah hal yang lazim dialami mahasiswa. (Santrock, 2012).

Kondisi belajar di perguruan tinggi yang toleran menuntut mahasiswa untuk mampu mengatur waktunya dengan baik dan belajar dengan mandiri. Namun dengan kondisi yang toleran dapat memunculkan kecenderungan perilaku penundaan akademik atau prokrastinasi akademik. Prokrastinasi merupakan penundaan yang tidak perlu pada aktifitas akademik, meskipun pada akhinya ada keinginan untuk menyelesaikan, prokrastinasi juga dapat menimbulkan kegelisahan (Solomon \& Rothblum dalam Hee Seo, 2008). Menurut Prayitno di antara salah satu faktor penentu kesuksesan mahasiswa di perguruan tinggi adalah sejauh mana mahasiswa tersebut mampu menyelesaikan dengan baik tugas-tugas yang diberikan oleh dosen dengan baik dan tepat waktu. 
Mahasiswa lebih merasa dewasa, punya banyak pilihan terhadap mata kuliah yang ingin diambil, punya lebih banyak waktu untuk bergaul dengan teman-teman, punya kesempatan yang lebih besar untuk mengeksplorasi nilai dan gaya hidup yang beragam, menikmati kebebasan yang lebih besar dari pantauan orang tua dan tertantang secara intelektual oleh tugas-tugas akademis (Santrock \& Halonen, 2010). Mahasiswa juga menghadapi tantangan manajemen waktu yang efektif, menghadapi ujian akademis, menghadapi rekan mahasiswa pada saat yang sama menangani urusan finansial, keluarga, dan pribadi (Gladding, 2012).

Dengan adanya kondisi tersebut sangat penting untuk mahasiswa agar mempunyai motivasi diri yang kuat dalam berprestasi. Dimyati \& Mudjiono, (2009) berpendapat bahwa motivasi dipandang sebagai dorongan mental yang menggerakkan dan mengarahkan perilaku manusia, termasuk perilaku belajar agar lebih semangat dan terdorong untuk menyelesaikan tugas-tugas yang dimiliki mahasiswa. Motivasi dapat dipandang sebagai suatu rantai reaksi yang dimulai dari adanya kebutuhan, kemudian timbul keinginan untuk memuaskannya (mencapai tujuan), sehingga menimbulkan ketegangan psikologis yang akan mengarahkan perilaku kepada tujuan (kepuasan).

Motivasi biasanya bersifat kompleks dimana perilaku seseorang bisa muncul dari beberapa motif yang terpisah. Misalnya motivasi seorang mahasiswa untuk meraih nilai tinggi bisa saja menopengi kebutuhannya untuk mendominasi atau menguasai (Feist, 2008). Kegiatan menguasai sesuatu merupakan bagian dari motivasi berpretasi. McClelland (Robbins, 2006) menjalaskan motivasi berprestasi merupakan suatu dorongan untuk unggul, untuk berprestasi berdasarkan seperangkat standar dan untuk berusaha keras supaya sukses. Sifat-sifat dasar orang dengan motivasi berprestasi yang tinggi yaitu (a) suka dengan keadaan yang dapat menyebabkan seseorang bertangggung jawab secara pribadi (b) cenderung menentukan sasaran yangs edang serta memperhitungkan resikonya, (c) keinginan untuk mendapatkan umpan balik yang ejlas atas kinerja (Uno,2007).

Hasil pengamatan di lapangan, sekitar $80 \%$ mahasiswa PAUD IKIP Veteran Semarang yang cenderung melakukan perilaku menunda tugas yang diberikan dosen, yang disebabkan karena kurangnya motivasi berprestasi untuk menyelesaikan tugas-tugas yang dimiliki mahasiswa. Dengan adanya kondisi tersebut menjadikan penulis ingin mengetahui bagaimana pengaruh self-efficacy dan prokastinasi akademik terhadap motivasi berprestasi pada mahasiswa PAUD IKIP Veteran Semarang.

\section{METODE}

Penelitian ini dilakukan menggunakan metode kuantitatif. Bungin menjelaskan metode kuantitatif bertujuan untuk mengetahui dengan jelas, meringkas kondisi dan situasi terhadap berbagai variabel yang ingin diteliti. Kemudian mengangkat kepermukaan gambaran tentang kondisi dan situasi antar variabel tersebut (Bungin, 2009). Subjek penelitian diambil kepada 79 mahasiswa yang sedang belajar di jurusan PAUD IKIP Veteran Semarang Tahun 2017. Pengambilan jumlah responden diambil dengan teknik simple random sampling. Alat yang digunakan untuk mengumpulkan data yaitu dengan menggunakan tiga skala yaitu skala self-efficacy yang merujuk kepada teori Bandura (1997), skala prokrastinasi akademik merujuk kepada teori Ferrary (1995) dan skala motivasi berprestasi merujuk kepada teori McClelland. Analisis data yang digunakan untuk menguji hipotesis mayor adalah dengan metode analisis regresi (Hadi,1995). 
Analisis ini bertujuan untuk mengetahui tinggi rendahnya nilai suatu variabel tergantung berdasarkan dua variabel bebas. Metode analisis yang digunakan untuk menguji hippotesis minor adalah korelasi parsial. Perhitungan menggunakan fasilitas program SPSS for windows versi 22.

\section{HASIL DAN PEMBAHASAN}

Berdasarkan pada matrik korelasi untuk menjawab tujuan penelitian minor antara self-efficacy dengan motivasi berpretasi diperoleh $\mathrm{r}=0,478$ dengan probabilitas $=0.000<0.05$, msks Ho ditolak, artinya ada hubungan positif yang signifikan antara self-efficacy dengan motivasi berprestasi. Ini berarti semakin tinggi self-efficacy seseorang maka semakin tinggi pula motivasi berprestasinya dan semakin rendah selfefficacy maka semakin rendah motivasi berprestasinya. Hal ini sesuai dengan yang diungkapkan oleh Rizvi (1997) bahwa seseorang dengan self-efficacy yang rendah akan memiliki pengharapan efikasi yang rendah, pengharapan hasil yang rendah serta nilai hasil yang kurang bermakna sehingga menimbulkan keyakinan yang tidak rasional terhadap kemampuannya.

Pada variabel prokrastinasi akademik dengan motivasi berprestasi untuk menjawab tujuan penelitian minor kedua diperoleh $\mathrm{r}=-0,618$ dengan probabilitas $=0.000<0.05$, maka Ho ditolak, yang berarti bahwa ada hubungan negatif yang signifikan antara prokrastinasi akademik dengan motivasi berprestasi. Untuk tanda negatif menggambarkan hubungan berlawanan yang artinya semakin tinggi prokastinasi akademik maka akan semakin rendah motivasi berprestasi dan semakin rendah prokrastinasi akademik maka semakin tinggi motivasi berprestasi. Hal ini selaras dengan penelitian Brownlow dan Readinger (2007) yang menemukan bahwa baik itu motivasi instrinsik dan ekstrinsik memiliki hubungan yang negatif dengan prokrastinasi akademik.

Hipotesis mayor pada penelitian ini adalah pengaruh antara self efficacy dan prokrastinasi akademik terhadap motivasi berprestasi. Hasilnya dapat dilihat pada tabel berikut.

\begin{tabular}{|l|r|r|r|r|}
\hline Model & $\mathrm{R}$ & $\begin{array}{c}\mathrm{R} \\
\text { Square }\end{array}$ & $\begin{array}{c}\text { Adjusted } \mathrm{R} \\
\text { Square }\end{array}$ & $\begin{array}{c}\text { Std. Error of } \\
\text { the Estimate }\end{array}$ \\
\hline 1 &, $618^{\mathrm{a}}$ &, 381 &, 373 & 6,32412 \\
2 &, $648^{\mathrm{b}}$ &, 420 &, 404 & 6,16598 \\
\hline
\end{tabular}

Output di atas pada model 1 untuk menjelaskan besarnya korelasi atau hubungan antara selfefficacy dengan motivasi berprestasi yaitu sebesar 0,618 dan besarnya pengaruh self-efficacy terhadap motivasi berprestasi yang disebut koefisien determnasi yang merupakan hasil dari pengukuran R. Dari output tersebut koefisien determinasi pada model (1) sebesar 0,381, yang artinya pengaruh variabel selfefficacy terhadap variabel motivasi berprestasi sebesar 38,1\%. Pada model (2) untuk menjelaskan besarnya nilai korelasi antara self-efficacy dan prokastinasi akademik terhadap motivasi berprestasi yaitu sebesar 0,648 dan prosentase pengaruhnya sebesar $42 \%$ sehingga dapat disimpulkan besarnya pengaruh self-efficacy terhadap motivasi berprestasi sebesar $38,1 \%$ dan pengaruh prokrastinasi akademik terhadap motivasi berpretasi sebesar $3,9 \%$. 
Berdasarkan hasil anova didapat Fhitung $=27,481$ dengan signifikansi $0.000<0,05$ maka regresi dapat dipakai untuk memprediksi motivasi berprestasi. Berdasarkan hasil regresi pada variabel self-efficacy diperoleh thitung $=2,236$ dengan probabilitas $0,028<0,05$ artinya ada pengaruh signifikan antara selfefficacy dengan motivasi berprestasi. Sedangkan pada prokastinasi akademik nilai $t$ hitung $=-5,009$ dengan probabilitas $0,000<0,05$ yang berarti ada pengaruh yang signifikan antara prokrastinasi akademik dengan motivasi berprestasi. Jadi berdasarkan hasil di atas maka hipotesis tujuan penelitian mayor diterima. Artinya ada pengaruh antara elf-efficacy dan prokrastinasi akademik terhadap motivasi berprestasi mahasiswa. Hasil hipotesis mayor tersebut sesuai dengan teori yang dikemukakan Bandura (Chu dan Choi, 2005) bahwa self efficacy berhubungan dengan prokrastinasi akademik. Self efficacy menunjukkan keyakinan untuk mengerjakan tugas sehingga dapat mencapai kesuksesan. Bandura menyimpulkan bahwa ketika terdapat tingkat kemampuan yang cukup dan motivasi, self efficacy akan mempengaruhi inisiasi dan keteguhan hati seseorang terhadap tugas.

Senecal, Koestner, dan Vallerand (Rakers, 2010) mengemukakan bahwa mahasiswa yang memiliki motivasi berprestasi untuk mengerjakan tugas akan cenderung untuk tidak menunda mengerjakan tugas yang diberikan. sikap prokrastinasi akademik tersebut dapat memberikan kerugian diantaranya adalah tugas tidak terselesaikan, atau terselesaikan namun hasilnya tidak maksimal, karena dikejar deadline. Menimbulkan kecemasan sepanjang waktu pengerjaan tugas, sehingga jumlah kesalahan tinggi karena individu mengerjakan dalam waktu yang sempit. Di samping itu, sulit berkonsentrasi karena ada perasaan cemas, sehingga motivasi belajar dan kepercayaan diri menjadi rendah.

Berdasarkan hasil deskriptif diperoleh data bahwa tingkat self-efficacy mahasiswa tergolong kategori tinggi dan tingkat prokrastinasi akademik tergolong sedang serta tingkat motivasi berprestasi mahasiswa tergolong tinggi. seharusnya jika secara keseluruhan self-efficacy dan motivasin berprestasi mahasiswa pada kategori tinggi, maka tentu resiko perilaku prokrastinasi akademik akan sangat rendah. Akan tetapi dalam hasil penelitian ini menunjukkan keadaan yang saling berkaitaan tersebut tidak terjadi pada mahasiswa yang diteliti. Dengan kata lain, tingginya keyakinan diri saja tidak cukup tanpa diimplementasikan dalam bentuk perbuatan secara nyata. Menurut analisa penulis, dimungkinkan adanya faktor-faktor lain yang menyebabkan mahasiswa masih cenderung berperilaku prokrastinasi akademik. Sehingga tidak terbukti adanya hubungan antara tingginya selfefficacy dan prokrastinasi akademik mahasiswa dalam menyelesaikan tugas perkuliahan. Hasil penelitian tidak sesuai dengan penelitian Zajacova et.al (2005) yang menunjukkan bahwa peranan self-efficacy sangat penting untuk mengatasi stres akademik, dan self-efficacy sangat berperan dalam mencapai keberhasilan akademik dan mengurangi perilaku prokrastinasi akademik mahasiswa di perguruan tinggi.

Sedangnya tingkat prokastinasi akademik dapat diartikan bahwa sebagian besar mahasiswa masih menunjukkan perilaku menunda-nunda untuk, memulai dan mengerjakan tugas perkuliahan sehingga menyebabkan keterlambatan dalam menyelesaikan tugas perkuliahan yang diberikan dosen. Hasil analisis juga menunjukkan bahwa sebagian besar mahasiswa masih berperilaku menundanunda tugas perkuliahan, sehingga penyelesaian tugas perkuliahan tidak terencana dengan baik dan tepat waktu. 
Perilaku penundaan tersebut di antaranya disebabkan oleh mahasiswa lebih cenderung melakukan hal-hal yang disenangi daripada mengerjakan tugas-tugas perkuliahan.

Prokastinasi akademik mahasiswa dipengaruhi oleh faktor internal dan eksernal. Faktor internal, yaitu faktor-faktor yang ada pada diri individu yang melakukan prokrastinasi, meliputi: (1) Kondisi fisik individu. Faktor dari dalam yang turut mempengaruhi prokrastinasi pada individu adalah keadaan fisik dan kondisi kesehatan seseorang; (2) Kondisi psikologis individu. Millgran dan Tenne menemukan bahwa kepribadian khususnya ciri kepribadian locus of control mempengaruhi seberapa banyak orang melakukan prokrastinasi. Sedangkan Faktor eksternal, yaitu faktor-faktor yang terdapat diluar diri individu yang mempengaruhi prokrastinasi. Faktor itu antara lain (1) Gaya pengasuhan orang tua. Hasil penelitian Ferrari menemukan bahwa tingkat pengasuhan otoriter ayah menyebabkan munculnya kecenderungan perilaku prokrastinasi; (2) Kondisi lingkungan. Prokrastinasi akademik lebih banyak dilakukan pada lingkungan yang rendah pengawasan dari pada lingkungan yang penuh pengawasan. Pergaulan individu pun turut mempengaruhinya.

Menurut pandangan teori Reinforcement menyatakan bahwa prokrastinator tidak pernah atau jarang menerima hukuman. Bahkan seorang pelaku prokrastinator merasa diuntungkan karena dengan menunda pengerjaan suatu tugas pada akhirnya selesai juga. Sedangkan teori cognitive behavioral menjelaskan bahwa perilaku menunda akibat dari kesalahan dalam berpikir dan adanya pikiran-pikiran yang irasional terhadap tugas seperti takut gagal dalam penyelesaian suatu tugas (Ferrari dan Morales, 2007). Seseorang dikatakan melakukan prokrastinasi apabila ia menunjukkan ciri-ciri antara lain takut gagal, impulsif, perfeksionis, pasif dan menunda-menunda sehingga melebihi tenggat waktu.

\section{SIMPULAN}

Berdasarkan hasil penelitian dapat disimpulkan bahwa ada pengaruh yang signifikan antara selfefficacy dan prokastinasi akademik terhadap motivasi berprestasi mahasiswa PAUD IKIP Veteran Semarang 2017. Ada hubungan positif yang signifikan antara self-efficacy dengan motivasi berprestasi. Ini berarti semakin tinggi self-efficacy seseorang maka semakin tinggi pula motivasi berprestasinya dan semakin rendah self-efficacy maka semakin rendah motivasi berprestasinya. Ada hubungan negatif yang signifikan antara prokrastinasi akademik dengan motivasi berprestasi, artinya semakin tinggi prokastinasi akademik maka akan semakin rendah motivasi berprestasi dan semakin rendah prokrastinasi akademik maka semakin tinggi motivasi berprestasi. 


\section{DAFTAR PUSTAKA}

Brownlow, S. \& Reasinger, R.D. 2000. Putting of until tomorrow what is better done today: Academic pocrastination as a function and proneness to boredom. Personality and individual differences, 24 (6), $837-846$

Bungin, B. 2009. Metode Penelitian Kuantitatif, Komunikasi, Ekonomi dan Kebijakan Publik Lainnya. Jakarta: Kencana

Bandura, A. 1997. Self-efficacy: The Exercise of Control. W.H. Freeman. New York.

Chu, Chun H. A. \& Choi, Jin Nam. (2005). Rethinking Procrastination:Positive Effects of "Active" Procrastination Behavior on Attitudesand Performance. The Journal of Social Psychology,145(3), 245-264.

Ferrari dan McCown. 1995. Procrastination and Task Avoidance: Theory, Research and Treatment. Plenum Press. New York.

Ferari dan Morales. 2007. Perceptions of Self-Concept and Self-Presentation by Procrastinators: Further Evidence. The Spanish Journal of Psychology 10 (1): 32.

Furchan, Arief. 2009. Beda Antara Belajar Di Sekolah Dan Di Perguruan Tinggi. (Diunduh, 25 November 2017). www.pendidikanislam.net.

Hadi, S. 1995. Analisis Regresi. Yogyakarta : Andi Offset.

Rakers, G. C. \& Dunn, K. E. 2010. The Impact of Online Graduate Students' Motivation and Self Regulation on Academic Procrastination. Journal of Interactive Online Learning. 9(1). 78-93. (Diunduh 10 November 2017). www.nclol.org/jiol/issues/PDF/9.1:5pdf.

Robbins, S. P. 2006. Perilaku Organisasi. Ahli bahasa: Benyamin Molan. Klaten: PT. Intan Sejati.

Solomon, L. J. \& Rothblum, E. D. 1984. Academic Procrastination: Frequency and Cognitive-Behavioral Correlates. Journal of Counseling Psychology, 31(4), 503-509.

Steel, P. 2007. The Nature of Procrastination: a Meta-Analytic and Theoretical of Quintessential SelfRegulatiory Failure. Psychological Bullerin, 133(1), 65-94. (Diunduh, 21 November 2017). http://my.ilstu. edu/ dfgrayb/Personal/Procrastination.pdf

Uno, H. B. 2007. Teori Motivasi dan Pengukurannya: Analisis di Bidang Pendidikan. Jakarta: Bumi Aksara.

Zajacova, A. Lynch, M,.S. and Thomas J. 2005. Espenshade Self-Efficacy, Stress, and Academic Success in College, Journal Research in Higher Education. 46 (6): 677 